\title{
Growth factors regulate proteinase activated receptor - 2 (PAR-2) on airway epithelium
}

\author{
Vivek Gandhi", Drew Nahirney, Harissios Vliagoftis \\ From Canadian Society of Allergy and Clinical Immunology Annual Scientific Meeting 2014 \\ Ottawa, ON, Canada. 23-26 October 2014
}

\begin{abstract}
Background
Many aeroallergens activate PAR-2 receptors on the airway epithelium. We have shown that PAR-2 activation participates in allergic sensitization and allergic airway inflammation in animal models of asthma. Moreover, PAR-2 is upregulated on the airway epithelium of asthmatics, but the mechanisms and factors responsible are unknown. As asthmatic airways are under various types of physiological stress, we hypothesized that cellular stress upregulates PAR-2 on airway epithelium and this upregulation is functional.
\end{abstract}

\section{Methods}

Human bronchial epithelial cells were cultured with or without growth factors for $24 \mathrm{hrs} / 48 \mathrm{hrs}$ and PAR-2 mRNA levels were studied by qRT-PCR. PAR-2 functions were assessed by measuring PAR-2-mediated calcium release from intracellular stores into the cytoplasm and IL-8 release in supernatants.

\section{Results}

We have previously shown that growth factor deprivation, but not oxidative stress or hypoxia, significantly upregulates PAR-2 mRNA in normal bronchial epithelial cells. We now show that growth factor deprivation also induces PAR-2 upregulation in airway epithelial cells from asthmatic individuals $(2.1+/-0.1$ fold, $n=2)$; this upregulation was reversible upon growth factor addition. We omitted individual growth factor from the culture media. Omission of only insulin caused significant PAR2 mRNA upregulation $(1.6+/-0.1$ fold, $n=4)$. In addition, supplementation of stressed cells with insulin reversed the growth factor deprivation-induced PAR-2 upregulation $(n=3)$. PAR-2-mediated activation of stressed cells induced more calcium release from

\footnotetext{
Pulmonary Research Group, Department of Medicine, University of Alberta,
} Edmonton, Alberta, T6G 2S2, Canada

C 2014 Gandhi et al; licensee BioMed Central Ltd. This is an Open Access article distributed under the terms of the Creative Commons Attribution License (http://creativecommons.org/licenses/by/4.0), which permits unrestricted use, distribution, and reproduction in any medium, provided the original work is properly cited. The Creative Commons Public Domain Dedication waiver (http:// creativecommons.org/publicdomain/zero/1.0/) applies to the data made available in this article, unless otherwise stated. internal stores and higher release of the inflammatory mediator IL-8 (2.1 +/- 0.2 fold, $\mathrm{n}=6)$ compared to nonstressed cells.

\section{Conclusions}

Growth factor deficiency could be the driving force for PAR-2 upregulation in asthmatic airways. Insulin may scription. In conditions of growth factor deprivation, PAR-2 upregulation may lead to increased activation of airway epithelial cells resulting in the higher release of pro-inflammatory mediators. Therefore, understanding PAR-2 regulation may allow the development of new anti-inflammatory approaches for airways diseases.

Published: 18 December 2014

doi:10.1186/1710-1492-10-S2-A11

Cite this article as: Gandhi et al.: Growth factors regulate proteinase activated receptor - 2 (PAR-2) on airway epithelium. Allergy, Asthma and Clinical Immunology 2014 10(Suppl 2):A11.

Submit your next manuscript to BioMed Central and take full advantage of:

- Convenient online submission

- Thorough peer review

- No space constraints or color figure charges

- Immediate publication on acceptance

- Inclusion in PubMed, CAS, Scopus and Google Scholar

- Research which is freely available for redistribution be one of the growth factors that regulate PAR-2 tran- 